\title{
Vulnerability, Legal Protection, and Work Conditions of Female Domestic Workers in Addis Ababa, Ethiopia
}

\author{
Kidist Mulugeta \\ Hone Mandefro \\ Ajanaw Alemie
}

\begin{abstract}
Domestic workers are one of the most vulnerable groups of workers. In Ethiopia, however, the vulnerability, legal protection, and work conditions of female domestic workers are not well-documented and researched. Hence, the purpose of this study was to investigate the vulnerability, legal protection, and work conditions of female domestic workers in Addis Ababa, Ethiopia. A cross-sectional qualitative research design was employed using in-depth interviews, key informant interviews, and focus group discussions. The study participants were 15 domestic workers, three officials from the Office of Labor and Social Affairs, and five brokers of domestic workers. Findings indicate that female domestic workers experienced abuse in various forms including verbal or psychological abuse, physical abuse, and sexual assault. Female domestic workers in the study area had few or no labor rights or protection. They rarely had clear contractual relations, worked long hours for low pay, and had little or no privacy. There is neither a proper state institution to promote the rights of domestic workers nor a strong viable movement among or on behalf of domestic workers. Hence, a relevant legislative framework developed by the city and national governments, and strong advocacy efforts to expose their working conditions are needed to improve the work conditions of female domestic workers.
\end{abstract}

Keywords: Addis Ababa, Ethiopia, female domestic workers, legal protection, work conditions, vulnerability

Domestic work has been one of the oldest occupations for millions of women around the world (International Labor Organization [ILO], 2010). All over the world, an important army of workers performs domestic tasks in private households in exchange for remuneration and/or board and lodging (Ramirez-Machado, 2004). According to the estimates of the ILO (2010), at least 52.6 million men and women were employed as domestic workers across the world. To put this into perspective, if all domestic workers worked in one country, this country would be the tenth largest employer worldwide (ILO, 2010). Domestic work is an important source of employment, and accounts for $1.7 \%$ of total employment worldwide and some $3.6 \%$ of all wage employment (ILO, 2013). The sector has particular importance in developing regions, such as Latin America and the Caribbean, where $11.9 \%$ of all paid employees are domestic workers. Likewise, domestic workers account for $8.0 \%$ of workers in the Middle East and 4.6\% in Africa (ILO, 2013).

Women in Ethiopia occupy a low status in the traditionally patriarchal society. Women experience lower socioeconomic status in general, and hence there is an unequal power relationship between men and women. Women face multiple forms of deprivation. Gender-

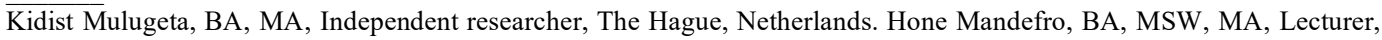
and Ajanaw Alemie, BA, MSW, Assistant Professor, Department of Social Work, University of Gondar, Gondar, Ethiopia.

Copyright (C) 2020 Authors, Vol. 20 No. 3 (Fall 2020), 532-558, DOI: 10.18060/23674

(cc) BY This work is licensed under a Creative Commons Attribution 4.0 International License. 
based discrimination, lack of protection of basic human rights, violence, lack of access to productive resources, education and training, basic health services, and employment are widespread. Ethiopian women suffer from work stereotypes and gender distribution of labor and more are occupied in economically invisible work (UN Women, 2014; WABEKBON Development Consultant, 2006). The gender parity index (GPI) at the primary school level was $98 \%$ in 2009/10 and dropped to $96 \%$ in 2012/13, indicating higher gaps in the enrollment of girls. This educational disparity is attributed to socio-economic challenges such as girls' responsibilities for time-consuming household chores and institutional challenges including the lack of gender-sensitive facilities and services at all levels. The majority of Ethiopian women have low levels of participation in formal sales and services, professional, technical, or managerial occupations. The largest rates of unemployment are recorded among adult and young women. Male employment was $84.7 \%$ in 2005 and $82.7 \%$ in 2013 whereas female employment was effectively static at $69 \%$ and $69.8 \%$, respectively (UN Women, 2014).

A conservative estimate indicates that at least 248,600 women are employed as domestic workers in Ethiopian cities. Estimates from the Ministry of Labor and Social Affairs (MOLSA) shows $1.5 \%$ of women in the country are currently working as domestic workers (Namukasa, 2011). Annabel and Tekleab (2007) reported that $15 \%$ of the female adolescent population in Addis Ababa were domestic workers, most of whom had migrated from rural areas. These domestic workers are often not aware of their rights and have little access to legal protection as they work within the confines of private homes and are thus vulnerable to domestic violence, abuse, and exploitation. The lack of protection of domestic workers in Egypt, Ethiopia, and Mali resulted in the violation of their rights which in turn exposed them to abuse and exploitation (African Union, 2015).

Previous studies on the background of domestic workers revealed an apparent reluctance of female citizens from Addis Ababa to pursue domestic work (Getachew, 2006). As a result, most domestic workers in Addis Ababa came from Amhara, Oromia, and Southern regions. A study in Addis Ababa found that "poverty of the family is the single most important cause (destitute family, disintegration of family or death of one or both parents) of children entering into domestic work" (Kifle, 2002, p. 26). Getachew (2006) added additional push factors that included escape from family violence, escape from unhappy and early marriage, and attraction to city life. As a result, the majority of domestic workers in Ethiopian cities are migrants from rural areas (Namukasa, 2011).

Most domestic workers in the study area have a low education level. For instance, a previous assessment of the educational level of domestic workers in Gulele sub-city of Addis Ababa found that only $40 \%$ of the respondents had attended primary school while the majority $(60 \%)$ were considered illiterate (Getachew, 2006). The dominance of women with low educational qualifications in the domestic work sector reflects the fact that the work does not require sophisticated skills or expertise. The work outlined in many families requires only the energy of youth and minimal orientation (Kifle, 2002).

The paths to joining the domestic labor market are important to understanding the situation of domestic workers. Kifle (2002) identified two main paths through which women become employed as domestic workers. The first is through a broker (delala in 
Amharic) where domestic workers are usually employed with a modest wage, and the second is through relatives or friends of the family in which the child finds temporary lodging with no pay.

The invisible work site (the home), the low status of the work, and the low level of education of the workers leaves domestic workers vulnerable to exploitation and abuse. At the theoretical level, legal protection for domestic workers is unavailable to some extent; however, at the practical level, legal protection is rarely implemented. With the background of the critical global situation of domestic workers, and also the historical lenience of a patriarchal culture until recently in Ethiopia, the work conditions, legal protection and capability of domestic workers to claim their rights is a neglected and under-researched area, resulting in many domestic workers accepting precarious and irregular employment relations and a life lived at or under the poverty threshold (Ramirez-Machado, 2004).

Previous studies on domestic workers in Ethiopia have neglected the legal protection of workers and focused on describing the vulnerabilities and work conditions of domestic workers from the perspective of domestic workers themselves. The views and perspectives of brokers and concerned government officials have not been taken into account. For instance, Annabel and Tekleab (2007) examined the invisibility and vulnerability of domestic workers in Addis Ababa, while Tagesse and Dubey (2017) addressed the forms of violence against female domestic workers in Hossana Town, Southern Ethiopia. Kedir and Rodgers (2018) provided an account of the profile of domestic workers, the significant drivers of participation in the provision of domestic services, and the welfare of unpaid and paid domestic workers in Ethiopia.

This study examined the legal protection, vulnerability, and work conditions of female domestic workers from the perspective of domestic workers, brokers, and government officials. Furthermore, whilst much scholarly attention in the field of domestic work focuses on protecting the rights and security of foreign/migrant domestic workers, the nature of domestic service work undertaken within national borders has largely escaped the attention of both researchers and public policymakers (Kedir \& Rodgers, 2018).

Hence, this study examined the following research questions:

- What are the experiences and vulnerabilities of female domestic workers in Yeka sub-city Addis Ababa, Ethiopia?

- What are the work conditions of female domestic workers in Yeka sub-city of Addis Ababa, Ethiopia?

- What factors do female domestic workers identify as correlated to such problems in their work environment?

- To what extent are the available rights of female domestic workers observed and implemented in the study area in relation to ILO labor mandates and other national legal instruments? 


\section{Definition and Scope of Domestic Work}

The ILO (2011) Convention on domestic workers takes a broad definition of domestic workers. According to ILO Convention (No. 189), Article 1:

(a) the term "domestic work" means work performed in or for a household or households; b) the term "domestic worker" means any person engaged in domestic work within an employment relationship; and (c) a person who performs domestic work only occasionally or sporadically and not on an occupational basis is not a domestic worker. (p. 1)

A domestic worker may be working in a country of which she/he is not a national. Domestic work includes mental, manual, and emotional aspects, including care work that is necessary to maintain people and communities (Anderson, 2000). However, there is no commonly agreed-upon definition across countries for what constitutes domestic work. The ILO's definition of domestic workers, which is based on the International Standard Classification of Occupations (ISCO), included four categories of domestic workers: (1) housekeepers and related workers, (2) childcare workers, (3) home-based personal care workers, and (4) domestic helpers and cleaners. A combined list of the four types of occupations mentioned above would give us a relatively comprehensive list of domestic workers including maids, cooks, waiters, gardeners, gatekeepers, chauffeurs, care takers, babysitters, and so on (Chen, 2011).

While the shared characteristics among domestic workers (low status, low educational level, mostly lacking protection, etc.) are profound, we should also note that considerable heterogeneity exists within the domestic worker's population and that the similarities should not mask the differences. One criteria of heterogeneity among domestic workers is the employment arrangements. Some domestic workers are hired by the employing household themselves or via a third-party agency. Some of the domestic workers work for a single employer, while others work for multiple employers. Some live within the premises of the house of their employer, while others live in their own home or with relatives. Some domestic workers may specialize in one specific task, while others are responsible for a variety of tasks (Chen, 2011).

\section{Feminization of Domestic Work}

From a historical perspective, one transformation of domestic work worldwide is the feminization of this form of labor. Studies indicate that domestic servants have not always been exclusively women. Until the middle of the $19^{\text {th }}$ century, the work was predominantly done by men in many European countries (Lutz, 2002). Following the industrialization and urbanization of many Western countries, the transformation of the rural servants into urban domestic workers, as the trend was known, led to feminization of domestic workers as a characteristic of urbanization and industrialization (Friese, 1991, cited in Lutz, 2002). Even then, Hill (1996) argues, there were sexual divisions of labor between male and female servants in the tasks they were assigned.

According to ILO (2013), in the contemporary world, domestic work remains a heavily female-dominated sector: women account for $83 \%$ of all domestic workers. Women's share 
among domestic workers ranges from approximately $63 \%$ in the Middle East to $92 \%$ in Latin America and the Caribbean. This makes domestic work a particularly significant source of wage employment for women, who often face greater obstacles than men in finding paid employment. Globally, one in every 13 female wage workers is a domestic worker (or 7.5\%); the ratio is as high as one in four in Latin America and the Caribbean (26.6\%) and almost one in three in the Middle East 31.8\% (ILO, 2013).

However, in Ethiopia, it is likely that domestic work has been women's occupation throughout history. Historical perspectives usually do not address this gender dimension of the issue. During the long extended time of slavery in Ethiopia, from which domestic work evolved and which was abolished only in the first half of the $20^{\text {th }}$ century, female slaves usually served in the home while male slaves worked in the agricultural fields (Pankhurst, 1968; cited in Tesfaye, 2007).

\section{Social Work, Power, Oppression and Human Rights}

Historically, the social work profession has identified the oppressed and marginalized as its focus areas and challenged inequities among individuals and groups. Social work originated from humanitarian and democratic ideas, which prompted the profession to challenge oppression, discrimination, and the unequal distribution of resources. This core value of challenging inequities, promoting democratic ideals, and championing human rights now forms part of the social worker's code of ethics. Since its inception, social work has been a human rights profession; the struggle for human rights remains a vital priority for the social work profession in the twenty-first century. Principles of human rights constitute an integral part of social work education, policy, and practice (Reichert, 2011).

The primary mission of the social work profession is to enhance human well-being and help meet the basic human needs of all people, with particular attention to the needs and empowerment of all people who are vulnerable, oppressed, and living in poverty (NASW, 2017). Oppression is an unjust use of authority or power over an individual or group. The different forms of oppression may be based on race, ethnicity, class, wealth, gender, and age. Each form of oppression creates a unique injustice and an inequitable power structure that allows it to both exist and perpetuate (Appleby et al., 2007, as cited in Reichert, 2011).

Power

Despite the presence of some form of labor legislation, domestic workers remain a vulnerable group and experience oppression in the form of exploitation, marginalization, powerlessness, violence, and some class-based cultural imperialism (Donald \& Mahlatji, 2006). Employers exercise a high degree of control over domestic workers. This extends to both their work and personal lives and is implemented through close supervision, suspicion regarding honesty, and restrictions on freedom of movement. Close supervision undermines the women's self-esteem and autonomy in performing their tasks and reinforces their lowly status. Relationships characterized by suspicion reflect a fundamental lack of trust and respect (Barrett et al., 1985).

Social workers are charged with the responsibility to challenge individual and social realities that create and perpetuate oppression and discrimination of vulnerable groups and 
individuals, thereby minimizing oppressive and discriminatory power relations and structures. Challenging oppression clearly is related to exercising human rights. Humanitarian and democratic ideals are anathema to oppression, which stems from inequitable distributions of power. In the struggle to reduce oppression, social workers must promote human rights (Reichert, 2011). Domestic workers are one of the vulnerable groups and the focus of social work interventions and services. Violence and abuse in the domestic arena touches all areas of social work including children, family, and community lives. Hence, social workers are responsible to intervene and work with the victims, their families, and perpetrators of abuse.

In recent years, the issues of domestic workers and their legal and social protection have been promoted by ILO (2011), Human Rights Watch $(2006,2008)$ and others as human and labor rights issues. The general tone of the activities of human right advocates is as follows:

Domestic/household workers have to be recognized as workers/employees. They need to be covered by labor legislation in each and every country, like any other workers. There is no place for "servitude" or discrimination in legislation. The vulnerability of migrant domestic/household workers needs extra attention. (International Restructuring Education Network Europe and International Union of Food, Agricultural, Hotel, Restaurant, Catering, Tobacco and Allied Workers' Associations, 2008, preface)

This study follows a human rights approach which "emphasizes that the rights of domestic workers are universal, stringent entitlements" (Albin \& Mantouvalou, 2012, p. 67). The year 2006 was a relevant point of departure as it marked the beginning of global efforts towards achieving protection for domestic workers all over the world. Human rights advocates and associations of domestic workers, whenever they exist, push towards the recognition of domestic workers as "workers" entitled to protection of their human and labor rights. These pressures culminated in the adoption of ILO Convention No. 189 (ILO, 2011, R2010) and supplementing Recommendation No. 201 (ILO, 2011, R201) which aimed at regulating the terms and conditions of work for domestic workers and which was used in this study as the standard to compare the realities of the living and working conditions of domestic workers.

ILO convention No.189 is an attempt to provide a framework for governments to provide domestic workers decent work, one of the human rights particularly promoted by ILO. Thus, the Convention is intended as a human rights instrument with an explicit claim of decent work as a human right for domestic workers.

This study, therefore, used a human rights-based approach as a framework to analyze the legal protection and work conditions of female domestic workers in the study area. Mary Robinson, Former High Commissioner for Human Rights defined the human rightsbased approach as:

A means of describing situations not in terms of human needs, or areas of development, but in terms of the obligation to respond to the rights of individuals. 
This approach empowers people to demand justice as a right, not as a charity. (De Alwis, 2008, p. 4)

The rights-based approach identifies claim-holders and corresponding duty-holders. The approach seeks to make duty-holders accountable to claim-holders, both in terms of protecting, promoting, and advancing these rights and in terms of preventing the violation of those rights (De Alwis, 2008).

\section{Theoretical Framework: Feminist Social Work Theory}

Since the early 1970s, the feminist perspective has been one of the predominant theoretical models in the domestic violence field, undergirding many programs, interventions, advocacy efforts, and legislative agendas (McPhail et al., 2007). Within social work, feminist thinking has a long history with several distinct perspectives. All of the perspectives share a deep concern for personal and social growth, as well as a linking of the personal and the political (Payne, 1991). Despite the existence of feminist thinking, feminist social work theory and practice as a theoretical construct is fairly new, appearing formally on the academic social work scene in a significant way during the late 1970s and early 1980s (Dominelli, 2002).

Feminist social work as a form of practice takes women's experience of the world as the starting point of its analysis and focuses on the links between a woman's position in society and her individual predicament, responds to her specific needs, and addresses structural inequalities. Feminist social work emphasizes addressing women's needs in a holistic manner and dealing with the complexities of their lives - including diverse forms of oppression impacting women's lives. Its focus on the interdependent nature of social relations ensures it also addresses the needs of those women that interact with the needs of men, children, and other women (Dominelli, 2002). Hence, the human rights framework and feminist social work provides an important theoretical guide to understand the vulnerability, violence, abuse, and exploitation of domestic workers. The historical lenience of a patriarchal culture in Ethiopia, the invisible work site (the home), the low status of the work, and inadequate legal protection exposes domestic workers to abuse and exploitation (Ramirez-Machado, 2004). In this study, the feminist social work theory helped to analyze the dynamics of abuse and exploitation as experienced by domestic workers.

\section{Vulnerability, Legal Protection and Work Conditions of Domestic Workers}

Domestic workers are one of the groups most vulnerable to exploitation, abuse, violence, harassment, and forced labor (Chuang, 2010; ILO, 2018; Ramirez-Machado, 2004). One of the sources of vulnerability is the intimacy that often characterizes the relationship between the employer and the domestic worker. Mantouvalou (2012) explained that such a "sense of intimacy can be false, though, because the relationship between the domestic worker and the employer is characterized by a difference of status that the latter is often keen to maintain" (p. 132). Sometimes the status difference can also have a cultural component in which the cultures of domestic workers serve as a basis for 
creating an asymmetric status between employing households and domestic workers. Rural styles of dressing, walking, and speaking which were taken as epitomes of backwardness and lack of civilization by the urbanite-elite employers are sources of vulnerability for domestic workers in Addis Ababa (Getachew, 2006).

Another source of vulnerability for domestic workers is the invisible site of work. The location of domestic labor (the home) leaves workers more vulnerable to abuse by employers (Mantouvalou, 2012). Domestic work is hard to supervise because accessing private homes is considered a violation of privacy. Live-in domestic workers are the most vulnerable. As domestic workers are living and working in their employer's home, their personal autonomy and mobility is negatively impacted and this can influence decisions as to their future, including the decision to start a family of their own (Tijdens \& Klaveren, 2011). Ramirez-Machado (2004) pinpoints that "the vulnerability [to abuse and discrimination] of domestic workers comes from the relationship of submission and their isolation" (p. 3).

Human rights violations against domestic workers such as physical violence, psychological violence, and sexual violence have been reported in several studies (e.g., Getachew, 2006; Tesfaye, 2007). In Ethiopia, as in many parts of the world, the extent of sexual violence of domestic workers is not fully known. Many women do not want to disclose their experience of sexual abuse and only a small portion of women report such cases (Anderson, 2000). Despite the lack of complete data, sexual abuse remains a common experience for many women. Domestic workers are more vulnerable to sexual abuse because they spend their time hidden in private homes, are in inferior positions, and are mostly women (Anderson, 2000).

Violence is a pattern of behavior employed by one person in a relationship to control the other (Yigzaw et al., 2004). Domestic violence is a common problem experienced by domestic workers. Violence can take three main forms: verbal or psychological abuse (including physical intimidation, threats of abandonment, and uttering humiliating things), physical abuse (any form of violent act which can result in physical harm including slapping, punching, kicking, beating with any object, twisting the arms, strangulation, using a knife or a gun) and sexual violence (an attempt or actual forced sex without the consent of the other party; Getachew, 2006; Tesfaye, 2007; Yigzaw et al., 2004).

Even though domestic violence is perhaps the most frequent type of human rights abuse in the world, in most studies the analysis of domestic violence is often restricted to violence against family members like women and children (Tesfaye, 2007). Thus, many studies ignore domestic violence against non-family members who reside within the same home such as domestic workers (Getachew, 2006). However, the lower and "outsider" status given to domestic workers leaves them prone to a number of abuses.

Despite growth, domestic work is poorly regulated, leaving the domestic labor workforce often unprotected by labor laws around the world. Domestic workers who work in isolation, where nobody is watching, are particularly vulnerable to violence and harassment at work. A workforce 67 million strong, domestic workers provide essential care in private homes; yet, they frequently suffer forms of violence and harassment, exploitation, coercion, ranging from verbal abuse to sexual violence, and sometimes even death. 
Domestic workers who live in the homes of their employers are especially vulnerable. For many, daily abuses like lack of rest and non-payment of wages can quickly turn into forced labor (D’Souza, 2010; ILO, 2018). Only about 10\% are covered by labor legislation to the same extent as other workers, while more than $25 \%$ are completely excluded. Less than half $(45 \%)$ of domestic workers have no entitlement to weekly rest periods/paid annual leave, and more than a third of women domestic workers have no maternity protection (Marcadent, n.d).

\section{Legal Instruments Relevant to Domestic Work}

The law is an important tool to promote legal and labor rights of women. In recent years, the issue of abuse and exploitation has been one agenda of international organizations like ILO, Human Rights Watch, and other regional entities. In 2011, ILO endorsed Convention No. 189 (decent work for domestic workers) along with Recommendation No. 201 that would provide protection to domestic workers in ratifying countries. Human Rights Watch $(2006,2008)$ has published a series of reports on the human right violations of domestic workers especially in Middle Eastern countries. Thus, domestic work is recognized as a form of labor and is already under existing international labor standards and human rights frameworks (cf. the ILO Convention No. 189 of Domestic Workers). However, still in the $21^{\text {st }}$ century, domestic work around the world is mainly informal and characterized by widespread violations of human and labor rights, ranging from the worst forms of child labor and bondage (Caracciolo et al., 2011). For the purpose of this study, two distinct sources of rights for women in Ethiopia were discussed: National laws and regional or international conventions.

\section{International Conventions}

In addition to local efforts, the government of Ethiopia has been among the first to become a signatory to the many international conventions (Biseswar, 2008). Some of these ratified conventions include: The Convention on the Elimination of All Forms of Discrimination Against Women (CEDAW; 1981), and the ILO Convention on Domestic Workers (2011).

Of these conventions, Hainfurther (2009) argues that, CEDAW is the most comprehensive and all-inclusive international convention in relation to promoting the rights of women. CEDAW is the sole international legal instrument specifically designed to promote and protect women's rights in a holistic and systemic way. CEDAW addresses gender inequalities in all spheres and at all levels within the family, community, market, and state. CEDAW recognizes and addresses violations of women's human rights in the private sphere of the home.

Furthermore, among the ILO instruments, Ethiopia is a party to the ILO convention No. 189 which provides important legal protection for domestic workers. The ILO Convention on Domestic Work is the major international legal instrument to promote decent work for domestic workers. This convention set the standards that states should strive to fulfil for domestic workers. The major components of this proclamation include: 
formation and termination of contracts, working hours and time off, remuneration, freedom of movement, and working conditions.

\section{National Laws}

The Federal Constitution of Ethiopia (Federal Democratic Republic of Ethiopia [FDRE], 1995) has demonstrated renewed legislative support for women thorough its various articles. For instance, Article 25 of the constitution prohibits discrimination based on gender. Article 35, which is entitled to and exclusively deals with the rights of women, has a total of 9 sub-articles detailing the rights of women, among others, to equal enjoyment of rights, entitlement to affirmative action, equal rights of property ownership, equality in employment and payment, and right of access to family planning education, information, and capacity. A number of other constitutional provisions, namely those embodied in articles 7, 33, 38, 42 and 89 also have a direct bearing on the protection of the rights of Ethiopian women (Biseswar, 2008).

However, the labor law proclamation number 377/2003 excludes domestic workers from coverage (FDRE, 1995). Although Article 3 (sub-article 3) of the proclamation states that the Council of Ministries will issue a special regulation concerning domestic workers, no such kind of regulation has been issued so far. This exclusion is contrary to CEDAW's demand of States to abolish "all other private instruments of any kind with a legal effect which is directed at restricting the legal capacity of women and shall be deemed null and void" (Article 15 sub-article 3).

The only legal document issued by the Ethiopian state that addresses domestic workers explicitly is the Ethiopian Civil Code which was endorsed in 1960 during the imperial government (Civil Code, 1960). A separate section in the Code deals with the contracts of domestic servants living in their employer's home. Accordingly, Article 2601 states that where the employee lives with the employer's family, the latter shall regard the livingquarters, food, times of work and rest and take all reasonable steps to safeguard the health and moral well-being of the employee (Civil Code, 1960, Article 2601, p. 432). Article 2602 declares the obligation of employers to look after the employee. However, sub-article three of the same article gives the power to the employer to "set off any expenses which he thus incurs against the wages that become due during the period of illness" (Civil Code, 1960, Article 2602, p. 433). Since the country was under feudalism, it is not surprising at that time the law reflected such paternalistic views since the awareness of human rights was low and employment protection was limited to the government sector.

In sum, there is a lack of adequate legal protection for domestic workers in Ethiopia. This has taken two manifestations: 1) in a form of constrained protection as reflected in the civil code of the country which has limited provisions on domestic workers where the intention seems to be humanitarian and not rights-based, and 2) total exclusion from labor laws of the country thereby lack recognition of domestic workers. For instance, the US Department of State (USDOS, 2015) Country Report on Human Rights Practices states that Ethiopian law specifically prohibits some categories of workers, including domestic workers, from organizing unions and notes that the informal sector as such, which includes domestic work, "is not unionized and is not protected by labor laws" (USDOS, 
2015, section 7a). However, the country has ratified the CEDAW, which can serve as a ground to claim the rights of domestic workers. This study, therefore, inquired about the extent to which the available rights of domestic workers are observed and implemented in the study area using the lens of national and relevant international human and labor rights instruments.

\section{Method}

\section{Research Paradigm}

The study purports the social constructivism research paradigm which assumes that individuals seek understanding of the world in which they live and work, where they develop subjective meanings of their experiences. These meanings are varied and multiple, leading to a search for the complexity of views rather than narrowing the meanings into a few categories or ideas. Hence, the approach of this study was to rely on the participants' views of the meaning and experience attributed to the work conditions, violence, and vulnerabilities of female domestic workers (Creswell, 2018). In this study, the social constructivism philosophy made it possible to employ a qualitative descriptive method using in-depth interviews, key informant interviews, and focus group discussion to collect data. Hence, in this study, the assumptions of social constructivism were relevant to explore how female domestic workers experience their work conditions, and the violence and vulnerabilities related to their work conditions and environment.

\section{Research Design}

This study used a cross-sectional, descriptive qualitative design to examine the vulnerability, legal protection, and work conditions of female domestic workers. In this regard, the primary aim was to search for hidden meanings, non-obvious features, multiple interpretations, implied connotations, and unheard voices (Have, 2004). Given the invisible nature of the domestic work site and the power differential between employer and employee, a qualitative approach was felt to be best suited to uncover such complexities and to examine the work conditions and vulnerabilities of female domestic workers.

\section{Study Participants and Selection Procedures}

The study participants were domestic workers, officials from the local Labor and Social Affairs Office, and brokers of domestic workers. Thus, the study aimed to consider the abuse, exploitation, and living and working conditions of domestic workers from the multiple perspectives of domestic workers, officials, and brokers of domestic workers. Participants were selected using purposive sampling techniques. Purposive sampling is a method commonly used in qualitative research that permits the researcher to carefully select participants because they represent some feature or process the researcher is interested in exploring (Silverman, 2000). The identification and selection of domestic workers was done through a local NGO in the study area which provides direct support for domestic workers to attend education and to protect themselves from HIV/AIDS. The name of the NGO is not disclosed here because the organization requested to remain confidential. The inclusion criteria for domestic workers included: (1) migrant workers from regions 
outside of Addis Ababa; and (2) having experience as a paid live-in domestic worker. The decision to limit the sample to paid, live-in workers is related to their increased interaction with employers.

\section{Data Collection Techniques and Procedures}

Three data collection techniques were employed: 1) direct, in-depth interviews with female domestic workers; 2) key informant interviews with brokers and officials from the Labor and Social Affairs office; and, 3) focus group discussions with domestic workers. The interview guides were prepared to structure the points to be discussed during each interview.

Two focus group discussions (FGDs), each consisting of seven female domestic workers, were conducted within the premises of the non-governmental organization office. The participants of the FGDs were the same as the interview participants. The focus of the FGDs was to uncover the underlying reasons behind the current working and living conditions of female domestic workers. Focus group discussions were employed to triangulate, substantiate, and cross-check responses of the in-depth and key informant interviews and to obtain information that may not be captured through key informant interviews (Kreuger, 1998). Accordingly, taking points from the completed interviews, discussants were asked to share their view on factors that could explain any possible exploitation or abuse. The researchers facilitated the FGDs.

The in-depth and focus group interviews with female domestic workers generated detailed data in response to questions such as: whether they are obliged or not to remain in the household or with its members during their periods of rest or leave (Article 9); are they benefiting from minimum wage standard, if any like other workers (Article 11); to whom do they report any actual or potential human rights violation threats by their employer or the middle persons and if any, what is the legal remedy they have been given so far by any concerned organization? Finally, what measures do they take in the absence of such legal help; are they informed of the employers or the host family`s ongoing situation such as the size of the household, tasks they are going to carry out, the working hours, and accommodations? Are they aware they have human rights that should be respected like every citizen? Does the reality usually meet their expectation which is based on the information they have been given by the middle person when they are employed?

Some of the questions asked for the key informant interviewees were:

- Had you personally have any contact with domestic workers in the town?

- Is there any program/intervention that your office is implementing in relation to domestic workers?

- Did your office ever receive any complaint from domestic workers?

If yes, would you summarize the main issues of complain so far?

$\circ$ What did happen to the complaint?

- If you were asked to summarize the problems faced by domestic workers in the city, how do you answer that question?

- Do you think Ethiopian law recognizes domestic workers as workers? 
- If yes, would you direct me to the relevant laws?

- If not, what is the position of your office on whether they need to be recognized as workers or not?

- What do you think are the factors that limited the legal recognition of domestic workers as workers?

The in-depth and key informant interviews were conducted at different locations. Some of the interviews with domestic workers took place in the cafeteria taking into account confidentiality, and some in the premises of the NGO office. Interviews with brokers were conducted in their offices or in the cafeteria around their work site suitable to conduct the interviews. Interviews with officials from the Labor and Social Affairs Office were conducted in their offices. The interviews and focus group discussions were conducted in Amharic language. The interviews were tape-recorded. The duration of each interview ranged from 40-60 minutes. The duration of each focus group discussion ranged from 6090 minutes.

\section{Data Analysis Techniques}

To analyze the qualitative data, thematic analysis was used. Transcribing and reading through the data is the first major procedure of data analysis in qualitative inquiry (Creswell, 2003). According to Braun and Clarke (2006), there are six phases for conducting thematic analysis which guided the data analysis of this study.

The first step is familiarization with the data. Initially, the verbal and nonverbal utterances of the in-depth interviews, key informant interviews, and FGDs were transcribed into written form. Then, the transcribed notes were read and re-read repetitively to uncover its original meanings as shared by participants. The second phase was coding, through which the researchers aim to generate succinct labels that can identify important features of the data; coding the entire dataset, then collating codes and extracting relevant data. Thirdly, searching for themes was accomplished by examining codes and the collated data to identify significant patterns of meaning. Each code was written on a separate piece of paper and organized into theme-piles. In organizing main themes and sub-themes, codes that did not seem to belong anywhere were collated and incorporated into miscellaneous categories. Fourthly, themes were reviewed carefully by checking candidate themes against the dataset to determine whether each of the themes really provided a convincing story to answer the research questions. Themes were also refined, split, combined, or discarded. The fifth phase was defining and naming themes so that the themes and data both coalesced meaningfully while simultaneously maintaining identifiable distinctions between them. After developing a detailed analysis of each theme, an informative name for each theme was given. In the final write-up, the researchers sought to weave together the analytic narrative and data extracts and contextualize the analysis in relation to existing literature.

\section{Ethical Considerations}

Given the hierarchical relationship domestic workers have with their employers, cautious measures were taken to ensure their safety. One such measure was to maintain the confidentiality of the participants. Only pseudo-names are used for domestic workers. 
Secondly, verbal consent was taken from every respondent. To ensure voluntary and informed consent, the researchers provided a clear description of the purpose and procedures of the study. Participants were told they could decline to answer any question they were not comfortable with, they could decline to be recorded at any point of the interview, and also, they could stop the interview at any time. In addition, based on the request of the nongovernmental organization where domestic workers were recruited for the interviews, the name of the organization was not disclosed.

\section{Results and Discussion}

Fifteen female domestic workers were selected to participate in the study. The average age of participants was 29 years old with a range of 21 to 37 years. Participants worked as a domestic worker for an average of 7 years (range of 4 to 12 years). Three participants came from Oromia region, eight were from Amhara region, three were from the Southern region, and one was from Tigray. Ten participants were divorced, three were single, one was married, and one was widowed. Concerning the participants' educational level: seven were uneducated, six attended up to primary school, and two attended secondary school.

The key informants for the study were brokers of domestic workers (through whom domestic workers are connected to households) and officials from the Labor and Social Affairs office of Addis Ababa City Government. Eight key informants were interviewed. Three of the key informants were from the Labor and Social Affairs office of Addis Ababa (one chair of the office, one social worker and one lawyer) while the remaining five were brokers of domestic workers in the study area, Megenaga area of Yeka sub-city, Addis Ababa.

\section{Work and Living Conditions of Female Domestic Workers}

Contract formation. The ILO convention no. 189 emphasizes the need for formal contracts between employers and domestic workers (ILO, 2011). The contract is a document that outlines the agreed upon terms in the event of a dispute. However, participants indicated that most (12 out of 15) do not have written contracts. One domestic worker, who had been working for five years in different households explained:

I did not enter into any contract. I came to the broker and waited for people who wanted to hire a domestic worker...If the broker asked me to deal with them, I ask the range of jobs to be done and tell them my salary. If they agree, then I will go with them trusting their words.

Similar stories were reported by other participants. Some of the domestic workers particularly those with few years of service, with no or little education, and those who migrated recently from rural areas - did not know what "contract" means. They had little awareness of contracts and their relevance and hence they did not request a contract. In addition, the brokers are well-informed of the terms of the verbal agreement and serve as witnesses in times of dispute. The verbal agreement usually is focused only on the amount of salary. 
Even when written contracts are produced, as was the case for three of the domestic workers, they have very limited general statements and are very brief. Ideally, according to the ILO convention 189, the contracts should include many details about where the work will happen, time of work, rest hours, salary, and so on. Of the many details that are supposed to appear in the contract, only two appear: name of both employer and employee and the amount of salary to be paid to the domestic workers. There is a pre-arranged form for both parties to sign once the salary amount is filled in.

\section{Precarious Working Conditions}

Work hours and time off. Domestic workers practically have no definitive work schedule, and often work long hours. The work hours of many domestic workers we talked to were extended. Many work for more than 16 hours per day. One domestic worker stated that in every household she worked for in the last ten years, the rule was that "domestic workers should work every time as long as there is something to be done." Another domestic worker explained that "usually I wake up 5:00 am to prepare breakfast for everyone in the house and then go to bed around 12:00 am after ensuring that everyone has got dinner."

Many of the domestic workers do not have any days off. One respondent stated that:

Having rest day is unimaginable in many ways. The task is so enormous and I am overloaded that I should work every time to finish. The madam does not want me to have a break and I cannot remember a day I took a rest.

She also stated that she sometimes argues with her madam on her overload and work without rest. However, her employer becomes nervous and frequently nagged her saying "you are here to work, not for vacation."

However, some domestic workers mentioned that they agree with their employer to have a day off during the time of employment and have one day a month to rest. Accordingly, the last Sunday of each month is their day off. However, they have no freedom to go out alone to the city without an accompanying household member. While many took it as a way of controlling and compromising their freedom, some of the domestic workers took it as provision of protection from the household to any possible danger while in the city.

Article 11 sub articles 1(e) of the CEDAW requires states to grant a paid leave for women workers. However, in violation of this right, findings showed that many domestic workers are forced to work long hours and are denied the right to rest and have leisure. This is also contrary to article $7(\mathrm{G})$ of the ILO domestic worker's convention No. 189 which demands paid leave and daily, weekly, and annual rest for domestic workers. Although the ILO domestic worker's convention No. 189 article 10 requests at least 24 consecutive hours of rest per week, this seems a pie in the sky for many domestic workers in the study area. Furthermore, while the workers sometimes complained, employers still required them to work long hours.

Low remuneration. The monthly salary of domestic workers at the time of data collection was in the range between 500 and 650 Birr (28 - 36 USD) per month. At its face 
value, this money cannot be considered as lower income by the country standard especially given the expectation that the food and accommodation of the workers is to be covered by employers. Even this amounts to almost two times the initial salary of public servants i.e, 357.00 Birr (21 USD) who work only 40-46 hours per week according to the labor laws of the country. However, the amount of money domestic workers earn is extremely low when we consider the long hours of work. If we break down this amount into payment per hour even a worker who worked for 14 hours, the smallest hours of work reported by participants of the study, then the maximum payment will be 1.5 Birr (0.09 USD) per hour. This payment is lower than $1 / 4$ of the lowest minimum wage for civil servants in the country.

Furthermore, some employers never pay the promised salary to domestic workers. Many of the participants had experienced dismissal without any salary after working for years. One participant, for instance, explained that,

It has been four months I am struggling to get my salary of six months from a household I have worked for 2 years. She always told me she will pay me in sum and it was better for me if the money is saved with her. But, after six months she dismissed me without my salary.

Yet, many of the domestic workers consider their present plight as a sacrifice for their better future, although they are insecure about what their life looks like in the future. One domestic worker said, "I am serving others hoping I will get something to serve myself later."

\section{Inadequate and Abusive Living Conditions}

Inadequate food and accommodation. Regarding food, in many cases discriminatory and dehumanizing practices were reported. One of most frequent forms of such dehumanizing practices is providing different food for domestic workers. One domestic worker says in her current household, she has never had the privilege to eat the same food as other household members. "I always eat the same food, Shero [a kind of sauce prepared from bean powder and is the cheapest food] with Injera" (local bread prepared out of powder of a tine grain called Teff). She says she never had adequate food to eat as her quota is two injera per day and Injera is given to her counted accordingly to keep separate for herself.

For many domestic workers, hunger is the most challenging problem since they have to work for long hours without taking proper food. One participant said she usually eats bread with tea in the morning and Injera with sauce in the evening, and nothing in between. Another participant said she left a household recently because she was always hungry. This participant added that she was supposed to work full day and night without any adequate food and even without mentioning it to her employer.

In relation to accommodations, most domestic workers indicated that they sleep in corridors or on a sofa within the salon. Some also reported that they sleep in the kitchen area of the house. One of the domestic workers indicated that she was forced to sleep on a veranda of the house: 
When the madam's friends come to the house to take drugs and chat together, they would not leave the house until late in the night and sometimes would stay at home throughout the night. In other days I sleep on the sofa but when they come, I have to sleep on the veranda. I have been sleeping there for three months.

This is contrary to even the humanitarian notion embedded in the rather outdated 1960 's civil law of the country. Although article 6201 of civil law does not promote rights of domestic workers, it demands employers of domestic servants to give adequate accommodation within their house. Similarly, it violates article 11 (e) of the CEDAW which demands the right to protection of health and to safety in working conditions. As the stories presented above show, this law indeed has been violated and domestic workers are provided with inadequate accommodations. The interview with officials in the Labor and Social Affairs Office indicated that there is little awareness of this right among workers and employers, and there has never been any inspection by the state related to implementing the provisions in the civil law or in the CEDAW.

Violation of privacy. Every participant indicated they experienced denial of privacy of varying degrees. In many cases, employers had a great degree of control over the workers' personal affairs. For instance, employers get furious to find out that their live-indomestic workers were involved in any sexual relationship. Reportedly, employers control their worker's social lives and do not allow them to develop any relationships with other people.

Domestic workers have restrictions on the calls they receive from relatives and friends. Some employers do not even allow any calls from outside while many allow only limited calls. One participant stated that her previous employer snatched her cell phone soon after she arrived in the house and told her that any kind of phone call is not allowed from her relatives and friends. The other participant said she left her previous home because she was not allowed to talk over the phone to her boyfriend.

Brokers whom we interviewed however saw the restriction of cell phones by employers differently. They explained that employers fear that by using cell phones domestic workers may make arrangements to steal expensive materials and runaway or they may give information to some other person to do the same and that such experiences happened to some employers.

\section{The Agony: Female Domestic Workers Experience of Violence and Abuse}

Verbal abuse. Verbal abuse is commonly experienced by domestic workers (Getachew, 2006; Tesfaye, 2007). In this study as well, verbal abuse against domestic workers was found to be frequent and widespread. The most common forms of verbal abuse mentioned by domestic workers included nagging, the use of derogatory labels, and jokes about domestic workers and their mistakes. Some other frequently mentioned types of verbal abuse included: "telling you to do something is like pouring water on a stone, for both there is to no effect," "you lazy...you are so dull, you stupid..."

The verbal abuse by the employers towards their domestic workers reflects the inferior position they ascribe to the workers. One of the domestic workers explained how her 
former employer used derogatory names to call her to deliberately hurt her psychologically: "she always calls me 'slave' and had never used my name. Every time I pass beside her and every time she looked at me in a way to remind me of my inferior position."

In this study, attempts were made to identify the perpetrators of the violence committed against domestic workers. The main perpetuators of verbal abuse according to domestic workers were female employers. Many of the domestic workers indicated that they have been belittled, nagged, threatened, or humiliated by madams (wives) more so than by male employers. This is contrary to the widely held view that men are the main perpetuators of violence and women are the victims (Getachew, 2006). However, this could also be understood as a result of more frequent interactions between domestic workers and madams compared to domestic workers and male employers. Many of the domestic workers indicated that they usually take orders from the wives, and the male employers have little role in giving them orders. Thus, the frequent contact between domestic workers and wives can be understood as leading to verbal abuse by wives against domestic workers. In some households, children were identified by domestic workers as the main perpetuators of verbal abuse. This indicates that domestic workers get the lowest status within the family below everyone in the household, including children.

Physical abuse. Physical abuse is not uncommon against live-in domestic workers. A significant number of stories of physical abuse were obtained from the in-depth interviews with domestic workers. The most common forms of physical abuse were slapping, being spat on, being kicked, or having nearby objects thrown at them. Presumed causes for physical abuse as viewed by the workers were mistakes while working, answering back to the instructions of employers, disagreements with family members, and sometimes even in the absence of any obvious reason, as a form of employers letting out their anger and frustrations.

As with verbal abuse, the main perpetuators of physical abuse against domestic workers were reported to be women. This emanates from the fact that the women (mainly housewives) are the ones who usually given instructions to domestic workers. For instance, one of the domestic workers with more than seven years of working in different houses explained her situation with her current employer:

I have been in conflict with the wife/mother of the house ..., she does not like the things I do and how I do them. So, she usually gives me specific instructions. But since sometimes I get overwhelmed by the workload around the house, I would either forget them or do them in another way. When this happens, she will abuse me and also beat me.

Another source of conflict between women and domestic workers is suspicion by housewives of any love affair between male employers and domestic workers. Such distrust will cause negative views by wives against domestic workers, which is expressed through abuse against domestic workers. One domestic worker explained:

The madam suspects me having a special relationship with her husband. She controls me in every detail like trying to make sure that I and her husband are not in the same room and are not talking. So, she expresses that by hitting and nagging 
me always. One day I was watching a movie on TV and she was asleep. The husband was also watching the movie and I was watching it sitting on the sofa with pyjama. All of a sudden, she came and beat me and told me that I should stop trying to seduce her husband otherwise she will beat me again and again.

Because of such frequent suspicions, many of the domestic workers indicated that they would prefer to work for single men than married households to avoid such abuses. However, female employers were not the only perpetuators of physical violence. For some domestic workers, violence came from other household members. Children also abuse domestic workers physically. One participant, who worked as a domestic worker for the last seven years, stated that in her current household, the biggest threat comes from the daughter in the family. She stated, "their daughter moved from abroad recently and she is making my life full of misery since her arrival. She always orders me to do many things and if I hesitate to do them, she slaps and hits me."

Sexual violence. The experiences of sexual abuse reported by the domestic workers ranged from unwanted body contact to attempted rape. The main perpetuators for sexual abuse were male employers and male adolescents in the home. Strangely, among the five attempted rapes reported by three domestic workers, four of the perpetuators were older men. This is culturally unacceptable among many Ethiopians who consider elderly people as wise, knowledgeable, and having ethics. This finding is also contrary to the widespread belief that sexual violence against domestic workers is mainly triggered by youth (Yigzaw et al., 2004). The characterization of elderly people as ethical, moral, and wise is contrary to their practice of sexual harassment against domestic workers within this sample.

\section{Explaining the Silence: Constrained Capacity of Female Domestic Workers and Unnoticed Plight of Female Domestic Workers}

The data about the work and living conditions of female domestic workers have clearly indicated how female domestic workers are enduring abuse, exploitation, and human rights violations. There is widespread violation of domestic workers' rights: restrictions on freedom of movement and communication, lack of adequate living and working conditions, denial of salary, refutation of privacy, and verbal, physical, and sexual abuse. One could therefore understand that the abuse domestic workers are experiencing rises to the level of trafficking.

Despite the high level of abuse and exploitation, there is no organized movement to enable domestic workers to claim their rights. Under CEDAW, women are guaranteed the right to equal exercise of the freedom of movement to protect their rights and to dismantle any disadvantage based on sex. However, there is no movement among domestic workers themselves or on behalf of them in the country to advocate for better living and working conditions for domestic workers. The lack of organized movement from the domestic workers themselves could be due to the nature of the work site since it is invisible which makes it difficult for domestic workers to come together and discuss their common problems. It seems that either their plight as domestic workers goes unnoticed or nobody cares enough to advocate on their behalf. 
Then what would be the main explanations for the lack of an organized movement against this gross injustice? One of the reasons for this may be related to the characteristics of domestic workers themselves. Due to historical, socio-political, and economic discrimination against women, domestic workers lack adequate awareness of human rights themselves, have low capabilities, and have no fall-back alternatives. Many of the workers in this study area were uneducated and none of them have education exceeding secondary school. Participants of the focus group discussion thought that their low level of education constrained their capacity to know their rights and also their capacity to claim their rights. "I am uneducated, hence don't know anything" was the common phrase that came again and again even during the focus group discussion. Similarly, a key informant from the Labor and Social Affairs Office explained:

One of the reasons for their acceptance of compromised working conditions, as I think is that most of them are not [well] educated. In some cases, where we had tried to help domestic workers, we realized that they do not know about rights issues. In a way this points out the need for awareness creation and capacitybuilding among the domestic worker's community.

The above quote indicates that there is a kind of victim-blaming from those officials who are partly responsible for creating good working condition for domestic workers. The institutional structures and policies are not responding well to the plight of domestic workers. Brokers also stated that though some employers want to hire educated workers, many prefer that domestic workers be less educated to enable them to "control and suppress them." As a result, migrants from rural areas and those who are less educated are preferred because their salary will be less than the educated ones. This indicates that the power inequality or powerlessness of domestic workers due to the oppression of their employers and brokers contributed to the violation of rights and violence and abuse of domestic workers. In addition, the widespread poverty in rural areas and lack of any other better opportunity in the city forces them to endure the exploitation hoping for betterment of their situations in the future. Almost all domestic workers in this study hoped one day to save money and start their own life rather than going back to the rural areas. Hence for them, today's exploitation and abuse are a sacrifice for their better future life, albeit the reality seems darker than they thought (Tegegne, 2009).

Furthermore, the hidden nature of the work site for domestic workers also contributed to their silence. Domestic workers live within the home, or on the same property as the employing family. Often, the family forbids the worker from leaving the premises alone and sometimes the worker will not be allowed to leave at all. Some employers compound domestic workers' isolation; this kind of seclusion involves forbidding any contact with the outside world - even through telephone or mail. The social exclusion created by the cloistering of migrant women in domestic service can take a heavy toll: many women do not have the opportunity to form friendships or create social ties. The resulting solitude exacerbates women's constructed vulnerability to abuse and deprives them of support networks when violations occur.

The state apparatus offers little help to alleviate the plight of domestic workers in Addis Ababa. The Labor and Social Affairs office of Yeka sub-city is at present lacking both the 
legitimacy and the manpower to assist domestic workers. Its lack of legitimacy emanates from the absence of a proper legal framework to oversee the situation of domestic workers. A key informant from the office said, "we had a number of cases where domestic workers come to us seeking assistance. However, mostly we do a kind of mediation between employer and employees since we lack the legal ground to inspect any violation." That is because the Labor Law Proclamation No. 377/2003 excludes domestic workers stating that the Council of Ministers will issue a specific regulation on domestic work (FDRE, 2003). However, after 15 years, the specific regulation has still not been issued. This indicates that both the legal and institutional structures lack appropriate responses for the problems and needs of domestic workers.

In addition, there are also key country-level factors that have a role in explaining the silence about human rights violations against domestic workers. The first and perhaps the most important is lack of political will at the country level. Plus, most politicians and policy-makers are personally benefiting from exploiting their own domestic workers. In fact, so many people in the cities are benefiting from rural domestic workers that it seems no one wants to speak up against the abuses. There is marginal emphasis on protection of workers in general and informal workers in particular. At one point the issue of legal protection for domestic workers was raised by one member of the parliament as an issue of concern. This lack of political will is also at the centre of the exclusion of domestic workers in many laws including the Ethiopian Labor Law Proclamation No. 377/2003. The proclamation No. 377/2003 does not include domestic workers (FDRE, 2003). Article 3 sub article 2(c) states that the proclamation does not include verbal contracts for personal service for non-profit making purposes. Furthermore, there is no proclamation that included the issue of domestic workers in the country's legal regime. This causes lack of de facto and de jure vulnerability of domestic workers in the country. The failure of ratification of many laws relevant to domestic workers including ILO convention no 187 is also related to lack of political will and commitment.

The second country-level factor playing a role in perpetuating the human rights abuses experienced by Ethiopian domestic workers is the lack of attention the issue has received among non-state actors. Most of the civil societies working in Ethiopia focus on issues like poverty reduction, health sector expansion, and vulnerable and orphaned children. "Even though there has been a proliferation of civil societies in Ethiopia in the last two decades, they focus heavily on food security and have almost no real links with Ethiopian organisations outside of government" (Center for International Studies at Dublin University, 2007, p. 9). Hence, it could be argued that the plight of domestic workers is confined to the households for which they work. They remain voiceless with no advocate to expose their miserable working and living conditions.

\section{Implications for Practice, Education and Future Research}

The findings of this study pinpoint a number of implications for social work practice education and future research. Given the gross human rights violations that domestic workers experience, such as precarious living and working conditions, physical, sexual and psychological abuses and exploitation, social workers need to be knowledgeable and skilled in identifying, assessing, and intervening with domestic workers. Social work 
training institutions are responsible to train and educate their students by incorporating course content on domestic violence in general, and with domestic violence against domestic workers in particular. In addition, including a feminist analysis of the issues and problems of domestic workers is also needed to enhance students' knowledge and understanding about the nature of domestic work and the plight of domestic workers. For a further understanding of domestic work and domestic workers in Ethiopia, additional research focusing on broader issues and areas of domestic work that can guide policies and interventions on domestic workers would have a significant contribution.

\section{Limitations of the Study}

A lack of well-organized statistics conducted on the area of domestic workers in Ethiopia was one of the challenges for this study. For instance, in selecting participants for the study, researchers intended to understand the major reason women migrate from rural to urban areas. Knowing this would have enabled researchers to ensure diversity in terms of the factors in selecting participants. However, no such data was found. Secondly, this study is a limited assessment of the vulnerability, legal protection, and work conditions of female domestic workers in the study area and its findings cannot speak about all the situations of domestic workers in Addis Ababa and/or in Ethiopia.

\section{Conclusion}

The findings of the study further support that there is a rhetoric commitment to women's rights in Ethiopia. The Ethiopian constitution (Article 35) declares equal rights of women in every aspect including in work and in some way calls for affirmative action to balance historical injustice against women. Similarly, in theory the national women's policy goals aim to bring equality to women, albeit that is too far to see at the moment. However, though the national women's policy identifies special vulnerable groups of women, domestic workers are not mentioned. In addition, if domestic workers are not part of the "women" group, they have been excluded from key labor laws such as Labor Law Proclamation No. 377/2003 (FDRE, 2003).

Female domestic workers in the study area were subject to gross human rights violations, exploitation and abuse such as lack of clear contracts and inapplicability of contracts, long hours of work, violations of privacy, verbal, physical and sexual harassment, inadequate food and accommodation, and poor payment. However, it is fairly difficult to argue that this violence and abuse against domestic workers emanates only due to the lack of legal protection for domestic workers. For instance, the country has ratified CEDAW and is party to the ILO convention No. 189 (although not yet ratified and domesticated). CEDAW prohibits any indirect discrimination of women in any sector and obliges states to ensure that the rights of women are protected. As such, the CEDAW could serve as a base to advocate for eradicating gross unjust practices like abuse and the inhumane treatment of domestic workers by their employers. For example, even by the outdated, civil code of the country (article 6201), employers are obligated to give adequate accommodation to their domestic workers which, as the findings showed is not observed or investigated by any government entity. 
Although legal protection for female domestic workers is limited in Ethiopia, some cultural factors (view of domestic workers as inferior and denial of any rights), illiteracy and severe poverty among workers themselves, contribute to the persistence of abuse against domestic workers and the persistent silence. The state has failed to show any political commitment to address these injustices. The national government also limited the spectrum for advocacy by civil societies mainly through a recent law which bans NGOs getting their funding from abroad to work on human right issues. As a result, there is neither a proper state institution to promote the rights of domestic workers nor a strong viable movement among or on behalf of domestic workers. Their suffering is hardly noticed and their voices remain in private homes, never in the public. Hence, developing a relevant legislative framework by the City government and the country as well, and strong advocacy efforts to expose their working conditions are needed to improve the lives of domestic workers.

\section{References}

African Union. (2015, April). Special initiative on domestic workers. First session of the specialised technical committee on social development, labor and employment, Addis Ababa, Ethiopia. https://au.int/sites/default/files/newsevents/working documents/28072-wd-special initiative on domestic workers- 1st_sdle-2015rev.1- tc-english.pdf

Albin, E., \& Mantouvalou, V. (2012). The ILO Convention on domestic workers: From the shadows to the light'. Industrial Law Journal, 41(1), 67-78. https://doi.org/ 10.1093/indlaw/dws001

Anderson, B. J. (2000). Doing the dirty work: The global politics of domestic labor. Zed Books.

Annabel, E., \& Tekleab, M. (2007). Invisible and vulnerable: Adolescent domestic workers in Addis Ababa, Ethiopia. Vulnerable Children and Youth Studies, 2(3), 246256. https://doi.org/10.1080/17450120701487857

Barrett, J., Dawber, A., Klugman, B., Obery, I., Schindler, J., \& Yawitch, J. (1985). South African women on the move. Zed Books.

Biseswar, I. (2008). A new discourse on gender in Ethiopia. African Identities, 6(4), 405429.

Braun, V., \& Clarke, V. (2006). Using thematic analysis in psychology. Qualitative Research in Psychology, 3(2). 77-101. https://doi.org/10.1191/1478088706qp063oa

Caracciolo, B., Henry, G., \& Rosenbusch, S. (2011). Domestic workers: From modernday slavery to equal rights, decent work, decent life. http://cms.horus.be/files/ 99931/MediaArchive/30 SOLIDAR_Briefing_Domestic_Workers.pdf

Centre for International Studies Dublin City University. (2007). Engagement with civil society in Ethiopia: Perspectives of Ethiopian CSOs, No. Paper 5. Dublin. 
Chen, M. A. (2011). Recognizing domestic workers, regulating domestic work: Conceptual, measurement, and regulatory challenges. Canadian Journal of Women and the Law, 23(1), 167-184. https://doi.org/10.3138/cjwl.23.1.167

Cherinet, H., \& Mulugeta, E. (2002). Country gender profile of Ethiopia. Prepared for the Swedish International Development Cooperation Agency (SIDA). https://hivhealth clearinghouse.unesco.org/sites/default/files/resources/1909 sida ethiopia.pdf

Chuang, J. (2010). Achieving accountability for migrant domestic worker abuse. North Carolina Law Review, 88, 1627-1656. https://digitalcommons.wcl.american.edu/ facsch lawrev/1052/

Civil Code of the Empire of Ethiopia Proclamation No. 165/1960. (1960). Negarit Gazette, Extra-Ordinary Issue No. 2, Addis Ababa. Ethiopia.

Convention on the Elimination of All Forms of Discrimination against Women. (1981). https://www.un.org/womenwatch/daw/cedaw/text/econvention.htm.

Creswell, J. W. (2003). Research designs: Qualitative, quantitative and mixed research methods approach (3rd ed.). Sage.

Creswell, J. W. (2018). Qualitative inquiry and research design: Choosing among the five approaches (4th ed.). Thousand Oaks, CA: Sage.

D'Souza, A. (2010). Moving towards decent work for domestic workers: An overview of the ILO's work. ILO Bureau of Gender Equality. http://ilo.org/wcmsp5/groups/public/--dgreports/---gender/documents/publication/wcms_142905.pdf

De Alwis, R. (2008). Disability rights, gender, and development: A resource tool for action full report. Wellesley Centers for Women, Wellesley College. https://www.un.org/disabilities/documents/Publication/UNWCW\%20MANUAL.pdf

Dominelli, L. (2002). Feminist social work theory and practice. Palgrave.

Donald, F. M., \& Mahlatji, L. (2006). Domestic workers' experiences of power and oppression in South Africa. Journal of Psychology in Africa, 2006(2), 205-214. https://doi.org/10.1080/14330237.2006.10820124

Federal Democratic Republic of Ethiopia [FDRE]. (1995). The Constitution of the Federal Democratic Republic of Ethiopia Proclamation no 1.1995. https://www.cabrisbo.org/en/documents/proclamation-no-1-1995-a-proclamation-to-pronounce-thecoming-into-effect-of-the-constitution-of-the-federal-democratic-republic-of-ethiopia

FDRE. (2003). Labor Law Proclamation no. 377/2003. Berhanena Selam Printing Press. http://www.ilo.org/dyn/travail/docs/327/Proclamation

Getachew, Y. (2006). Cross sectional assessment of violence against female domestic workers in Gulele Sub-City for local level intervention (Master's thesis). Addis Ababa: Addis Ababa University. http://213.55.95.56/handle/123456789/ 2837? show $=$ full 
Hainfurther, J. S. (2009). A rights-based approach: Using CEDAW to protect the human rights of migrant workers. American University International Law Review, 24(5), 843-895. https://digitalcommons.wcl.american.edu/cgi/viewcontent.cgi?article= 1106\& context=auilr

Have, P. (2004). Understanding qualitative research and ethno-methodology. Sage.

Hill, B. (1996). Servants: English Domestics in the Eighteenth Century. Clarendon Press.

Human Rights Watch [HRW]. (2006). Swept under the rug: Abuses against domestic workers around the world. https://www.hrw.org/reports/2006/wrd0706/

HRW. (2008). "As if I am not human”: Abuses against Asian domestic workers in Saudi Arabia. https://www.hrw.org/reports/2008/saudiarabia0708/

International Labor Organization [ILO]. (2010). Decent work for domestic workers. http://www.ilo.org/wcmsp5/groups/public/---ed norm/--relconf/documents/meetingdocument/wcms 104700.pdf

ILO. (2011). C189 - Domestic Workers Convention on Decent Work, 2011 (No. 189). http://www.ilo.org/dyn/normlex/en/f?p=NORMLEXPUB:12100:0::NO::P12100 INS TRUMENT ID:2551460\#A1-

ILO. (2011). R201 - Recommendation on decent work for domestic workers (No. 201). https://www.ilo.org/dyn/normlex/en/f?p=NORMLEXPUB:12100:0::NO::P12100_IN STRUMENT ID:2551502.

ILO. (2013). Domestic workers across the world: Global and regional statistics and the extent of legal protection. https://www.ilo.org/wcmsp5/groups/public/ ---dgreports/---dcomm/---publ/documents/publication/wcms 173363.pdf

ILO. (2018). Domestic work: Recognizing the rights of domestic workers. https://www.ilo.org/global/about-the-ilo/mission-andobjectives/features/WCMS_641738/lang--en/index.htm

International Restructuring Education Network Europe (IRENE) and International Union of Food, Agricultural, Hotel, Restaurant, Catering, Tobacco and Allied Workers' Associations (IUF). (2008). Respects and rights: Protection for domestic/household workers! https://idwfed.org/en/resources/report-of-the-international-conferencerespect-and-rights-protection-for-domestic-workers/@@display-file/attachment_1

Kedir, A., \& Rodgers, P. (2018). Household survey evidence on domestic workers in Ethiopia. The Service Industries Journal, 38(11-12), 824-840. https://doi.org/ $\underline{10.1080 / 02642069.2018 .1484111}$

Kifle, A. (2002). Child domestic workers in Addis Ababa: A rapid assessment. IPEC. https://www.ilo.org/ipec/Informationresources/WCMS 113249/lang--en/index.htm

Krueger, R. A. (1998). Focus groups: A practical guide for applied research. Sage.

Lutz, H. (2002). At your service Madam! The globalization of domestic service. Feminist Review 70(1), 89-104. https://doi.org/10.1057/palgrave/fr/9400004 
Mantouvalou, V. (2012). Human rights for precarious workers: The legislative precariousness of domestic labor. Comparative Labor Law and Policy Journal, 34, 133-166.

Marcadent, P. (n.d). Domestic workers: Snapshot ILO in action. https://www.ilo.org/wcmsp5/groups/public/---ed protect/---protrav/--travail/documents/publication/wcms 214499.pdf

McPhail, B. A., Busch, N. B., Kulkarni, S., \& Rice, G. (2007). An integrative feminist model: The evolving feminist perspective on intimate partner violence. Violence Against Women, 13(8), 817-841. https://doi.org/10.1177/1077801207302039

Motsei, M. (1990, July). The best kept secret: Violence against domestic workers. Paper presented at the Centre for the Study of Violence and Reconciliation [Seminar No. 5]. University of the Witwatersrand, Johannesburg, South Africa. https://www.csvr.org.za/ publications/1589-the-best-kept-secret-violence-against-domestic-workers

Namukasa, A. (2011). Africa. In H. Schwenken \& L.-M. Heimeshoff (Eds.), Domestic workers count global data on an often-invisible sector (p. 16-23). https://www.unikassel.de/upress/online/frei/978-3-86219-050-8.volltext.frei.pdf

National Association of Social Workers. (2017). Code of ethics, as Revised. Washington, DC: NASW Press. https://www.socialworkers.org/About/Ethics/Code-ofEthics/Code-of-Ethics-English

Payne, M. (1991). Modern social work theory: A critical introduction. Macmillan.

Ramirez-Machado, J. M. (2004). Domestic work, conditions of work and employment: A legal perspective. International Labor Office. https://www.ilo.org/travail/whatwedo/ publications/WCMS_TRAVAIL_PUB 7/lang--en/index.htm

Reichert, E. (2011). Social work and human rights: A foundation for policy and practice, (2nd ed.). Columbia University Press.

Silverman, D. (2000). Doing qualitative research: A practical handbook. Sage.

Tagesse, L., \& Dubey, R. (2017). Forms of violence against female domestic workers: The case of Hossana Town, Hadiyya Zone, Ethiopia. Imperial Journal of Interdisciplinary Research, 3(8), 684-688.

Tegegne, A. E. (2009). Migrant women's vulnerabilities: A research reconnaissance in Addis Ababa. Ethiopia. Erasmus University. https://www.semanticscholar.org/paper/ Migrant-Women $\% \mathrm{E} 2 \% 80 \% 99 \mathrm{~s}-$ Vulnerabilities\%3A-A-research-inTegegne/ae475e489214bb45c98fb45021278d5a9a28cbd7

Tesfaye, S. (2007). Denial of rights, human rights abuses and violence against domestic workers in some selected areas of Addis Ababa (Master's Thesis). Addis Ababa: Addis Ababa University. http://etd.aau.edu.et/handle/123456789/7067

Tijdens, K., \& Klaveren, M. (2011). Domestic workers, their wages and work in 12 countries. University of Amsterdam, The Netherlands. 
https://www.semanticscholar.org/paper/Domestic-workers\%3A-their-wages-andwork-in-12-Tijdens-Klaveren/e3fe191a0eb231d84773bf4c10ee5b0c1180169b

UN Women, (2014). Preliminary gender profile of Ethiopia. https://20122017.usaid.gov/sites/default/files/documents/1860/Preliminary\%20Gender\%20Profil e \%20of\%20Ethiopia \%20Nov\%2017\%20final.pdf

USDOS - US Department of State. (2015). Country report on human rights practices 2014 -Ethiopia. https://www.ecoi.net/local_link/306259/429638_en.html

WABEKBON Development Consultant. (2006). Ethiopia: Country gender profile. https://www.jica.go.jp/english/our_work/thematic issues/gender/background/pdf/e06 eth.pdf

Yigzaw, T., Yibric, A., \& Kebede, Y. (2004). Domestic violence around Gondar in Northwest Ethiopia. Ethiopian Journal of Health Development, 18(3), 133-139. https://doi.org/10.4314/ejhd.v18i3.9846

Author note: Address correspondence to Kidist Mulugeta, Independent Researcher, The Hague, Netherlands. Email: kiddomul@gmail.com 